\title{
Who Signs? Ballot Petition Signatures as Political Participation
}

\author{
Brian Amos \\ University of North Florida \\ brianamos@gmail.com \\ Diana Forster \\ American Institutes for Research \\ adianaforster@gmail.com \\ Daniel A. Smith \\ University of Florida \\ dasmith@ufl.edu
}

\begin{abstract}
Who signs ballot initiative petitions? Do they fit a particular socio-political and demographic profile of a likely voter, or are they peripheral voters who become engaged in the political process due to the issue at hand? And are some citizens who sign petitions more likely to have valid signatures than others? Scholars have been slow to assess who is likely to become engaged in perhaps one of the most common forms of political participation: signing a ballot petitions. Drawing on an original dataset of individual-level data, we use GIS and logit models to test which citizens were more likely to sign a controversial local ballot petition, as well as to determine who was likely to sign a valid (or invalid) petition.
\end{abstract}

\section{Introduction}

A healthy democracy is predicated on political participation, but who becomes civically engaged is often constrained by socioeconomic status, personal resources (including money, time, and skills), partisanship, formal education and income, and a host of institutional factors (Rosenstone and Hansen 1993; Schlozman, Verba, and Brady 2012). In addition to who votes (Wolfinger and Rosenstone 1980), scholars have investigated who is more or less likely to contribute money to a political party, join a political organization, write a letter to a public official or speak up at a public meeting. Yet, we know much less about who is likely to participate in one of the most common forms of civic engagement in the United States-signing a statewide or local ballot petition-despite the fact that every year tens of millions of individuals serve as citizen lawmakers (Bowler, Donovan, and Tolbert 1998; Matsusaka 2004).

Beyond contributing to the academic debate over whether the process of direct democracy has the potential to politically engage and mobilize citizens (Magleby 1984; Bowler and Donovan 1998; Smith and Tolbert 2004; Donovan, Tolbert, and Smith 2009; Dyck and Seabrook 2010), the question of who actually signs ballot petitions has several real-world implications. First, at both the state and local level, firms gathering petitions want to target individuals who are likely to provide valid signatures. Knowledge of who is likely to sign a ballot measure is of no small interest. The "initiative industrial complex" (Magleby and Patterson 1998) is big business (Broder 2000). Second, election administrators must validate ballot petitions. Some rely on formulas to estimate the number of valid signatures submitted on 
petitions, but little is known whether registered voters are equally likely to sign valid petitions (Donovan and Smith 2008). Third, proponents and opponents of ballot measures have a keen interest in knowing who is more likely to sign a valid ballot petition. Proponents are interested in assuring that the signatures their volunteers and paid petition gatherers collect are legitimate (Nall, Schneer, and Carpenter 2018); opponents are interested in disqualifying measures from the ballot by demonstrating irregularities, or even pervasive fraud in the signature gathering process (Donovan and Smith 1998). Yet, with few exceptions, scholars have not investigated who is more likely to sign ballot petitions, or whether some individuals are more likely to provide valid signatures on petitions submitted for verification.

The dearth of scholarly research on who signs ballot petitions is surprising given the number of lawsuits dealing with the signature gathering process (Smith 2012). Most recently, in the United States Supreme Court's 2010 decision, Doe v. Reed, an 8-1 majority found that the more than 137,000 individuals who signed petitions that were submitted to the state of Washington to qualify a popular referendum did not have a constitutional right to keep their identities private. Absent in the litigation was any discussion of the political or sociodemographic profile of those individuals who signed the anti-gay marriage petitions, much less any empirical evidence investigating the underlying motivations of those who signed petitions. ${ }^{1}$

Building on the political participation literature, we offer rival theoretical explanations for why some individuals might be more willing than others to sign ballot measure petitions and why some individuals might be less likely than others to provide valid information when signing. We test our theories by drawing on an observational dataset of more than 8,000 signatures collected over a period of six months in 2008 by proponents of a local ballot initiative in the City of Gainesville, Florida. The initiative was designed by proponents to overturn a city ordinance protecting lesbian, gay, bisexual, and transgender (LGBT) individuals from employment and housing discrimination. In order to determine which registered voters in the city were more likely to sign the ballot petition, we link the unique voter identification number of those individuals who signed petitions with their official voter registration records maintained by the Alachua County Supervisor of Elections, which oversaw the election. In addition to assessing the socio-demographic and partisan dimensions of who was more likely to sign the socially conservative ballot initiative, we analyze which registered voters in Alachua County were more likely to sign a valid petition. We augment our empirical findings with a GIS spatial analysis to determine whether the geographical location of a voter's residence is related to registered voters signing an invalid petition.

\section{Valid and Invalid Petitions: Who Signs, and Why?}

If signing a ballot measure petition constitutes a political act, who is more likely to sign a petition, and why? Despite advances in our knowledge of political participation, few studies have delved into petition signing as a political act. In their classic study of mobilization and political participation, Rosenstone and Hansen (1993) are an exception. According to their analysis of American National Election Studies (ANES) survey data, 38 percent of white

1 See, for example, "Brief Amici Curiae of Direct Democracy Scholars in Support of Respondents," Doe v. Reed, Supreme Court of the United States. Available: http://electionlawblog.org/archives/smith-doe.pdf. 
respondents reported signing a petition, while only 18 percent of blacks reported such activity. They also find that wealthier individuals are more likely to sign a petition, arguing that they are presented with more opportunities to sign petitions than those who are poorer. But they find that signing a petition is not correlated with the other political activities, including voting, writing a Congress member, or attending rallies. "Petition signing," Rosenstone and Hansen (1993: 82) conclude, “depends less on a person's propensity to act than on a person's likelihood of encountering somebody who is carrying a petition," with those more socially networked are more likely to sign petitions. Unfortunately, the national survey data Rosenstone and Hansen draw on for their study of petition signing is not limited to signing ballot petitions at either the state or local levels.

Drawing on county-level aggregate data to analyze signatures gathered for eight statewide initiatives in California between 2000 and 2003, Boehmke and Alvarez (2014) find that the statewide distribution of signatures across the state's 58 counties was equitable relative to their population, although there was considerable variation in the counties' validity rates for signatures. In terms of the total number of signatures gathered across the initiatives, petitioners collected more signatures in larger, more densely populated counties with younger populations, lower rates of unemployment, and higher GINI Indices. They find no evidence that a county's percent of the voting age population with a high school degree, its partisan composition, or its percent of blacks or Hispanics, affected the number of signatures gathered, nor that a county's competitiveness correlated to where petitioners gathered signatures. Drawing random samples of submitted signatures, they also estimate signature validity rates. They report that proponents successfully gathered approximately 50 percent more signatures than were necessary to place the measures on the ballots. However, they find little indication that the invalid rate of signatures across counties was related to a county's socio-demographics or partisanship, but that counties with higher unemployment rates had significantly lower invalid rates. Though highly speculative due to ecological inference limitations, Boehmke and Alvarez (2014: 9) suggest that "signature gathering campaigns are targeting less politically active and disaffected citizens" and that residents of these counties "may be targeted either because voters may be less trustful of elected officials or, more cynically, they may be more likely to sign petitions without much reflection or objection." They note, however, that scholars have yet to use individual-level data to assess "where the good signatures are."

As a result, scholars know little about who signs ballot petitions, and why. Theoretically, one reason some individuals might be willing to sign petitions is that they are motivated by ideology. Some individuals who sign petitions might be inspired by the issue, agreeing with its substantive content and wanting to support the cause. As evidence, scholars point to the fact that petition signers are more knowledgeable of and more interested in a ballot measure's subject matter than non-signers (Neiman and Gottdiener 1982). But other scholars have shown that elite endorsements have only a conditional effect on helping citizens overcome their knowledge deficits about ballot measures (Burnett and Parry 2014) and that those who sign may not be any more likely to be directly affected by a petition's goals (Stein, et al. 1983). Still, there may be an iterative leaning process going on, as the very process of being asked to sign a 
petition may spur a genuine interest in the topic, or even turning out to vote if the measure appears on the ballot (Parry, Smith, and Henry 2012).

An alternative reason as to why some individuals sign petitions is that they are motivated by pro-social behavior. If there is evidence that many individuals struggle to understand the text of ballot measures (Reilly and Richey 2011; Burnett and Kogan 2015), it raises doubt as to whether those who sign petitions during the qualification phase do so for ideological reasons. The social psychology literature suggests a second motivation for signing a petition, namely that it is a non-ideological form of "prosocial behavior" (Helson, et al. 1958). Those who sign a ballot petition may do so merely in support of placing the initiative or referendum on the ballot; it is not necessarily a signal that they support-or are even aware ofthe substance of the measure. "Most people trust the petition circulator's description of the proposition to be accurate," Magleby (1984: 62-3) notes, "and they desire to comply with the request for assistance." It is possible, then, that pro-social behavior may entice some individuals to sign petitions, irrespective of their ideological priors.

A secondary question concerning petition signing as a form of political participation is whether some individuals are more likely than others to have their signatures invalidated. In practice, there are myriad reasons why an individual's signature (and accompanying information, including name, address, and date) on a petition might be rejected by state or local elections officials. Administrators tasked with validating signatures often have wide discretion when determining the veracity of signatures as well as any additional information submitted on a petition. We are interested in whether some registered voters are more likely than others to sign multiple ballot petitions, as well as if those who sign invalid petitions might do so because they live at the edge of a jurisdiction's limits. Although scholars have found that signing an invalid or duplicate petition is not uncommon (Donovan and Smith 2008), they have not used individuallevel data to assess which registered voters are more likely to sign petitions that later are invalidated. For example, individuals motivated by ideology might be motivated to sign multiple petitions, overzealous to qualify the issue, or even sign petitions beyond the jurisdiction in which they reside. Alternatively, individuals driven by prosocial tendencies may sign petitions multiple times, or sign them even though they do not reside in the jurisdiction just to appease signature gatherers. Given data limitations, of course, we can only speculate as to motivational factors that lead to higher levels of invalid or duplicate signatures, but we can assess the demographic, partisan, and geographic profiles of registered voters who sign petitions that are rejected.

\section{Research Design, Data, and Expectations}

To examine who signs petitions, we turn to an original dataset of thousands of individuals who signed a local initiative petition in the City of Gainesville, Florida, during the first six months of 2008. After an intensive grassroots petition gathering effort led by the conservative issue group, Citizens for Good Public Policy, proponents of the local initiative collected a sufficient number of valid signatures to place the charter amendment on the municipal ballot. The group collected over 8,700 petitions, of which the Alachua County Supervisor of Elections accepted 6,379 with a valid name, signature, address of a registered voter in the City of Gainesville, and properly 
counter-signed by the petition gatherer. The proponent's appeal to conservatives to sign the petition was explicit. "The high number of petitions signed by the citizens of Gainesville," stated Citizens for Good Public Policy chairman, Cain Davis, upon submitting petitions to the Alachua County Supervisor of Elections, "serves as an indicator of the power held by citizens over elected officials who choose to push a far-left national agenda” (Catholic News Agency 2008).

What would become known as "Issue 1" sought to prohibit Gainesville from adding to its charter any protections, preferences, or anti-discrimination ordinances not explicitly guaranteed in the Florida Civil Rights Act. Adoption of the measure would have voided existing ordinances on sexual orientation and gender identity, thus forcing the city's human rights ordinances to mirror the Florida Civil Rights Act. Because Gainesville's human rights ordinances included sexual orientation and gender identity while the Florida Civil Rights Act did not, the measure would have effectively repealed a provision passed by the city commission in January, 2008, that protected LGBT individuals in the city. The ensuing "No on 1" campaign was led by the political action committee, Equality is Gainesville's Business, which worked with the American Civil Liberties Union and other groups to defeat the measure. On March 24, 2009 , the ballot measure was defeated; 58.3 percent of the 20,114 voters casting ballots voted no on the measure.

In order to conduct our analysis, we purchased from the Alachua County Supervisor of Elections a list of all the individuals who signed petitions for Issue 1 and linked them to the Alachua County voter file (which includes the City of Gainesville), which we obtained from the Florida Secretary of State through a public records request. Although not as comprehensive as most survey data with respect to individual-level information, the voter file includes demographic and partisan information about the registered voters who both signed and did not sign the petitions, including race and ethnicity, gender, age, party, residence, and vote history. Our base model is comprised of all 63,967 individuals who were registered to vote in the City of Gainesville as of August 1, 2008. It includes 7,993 individuals registered to vote in the city and who signed a petition (subsequently determined to be either valid or invalid) and for whom we have complete demographic data from the Alachua County voter registration file. We have no data for 760 individuals who signed a petition but who did not exist in the statewide voter file or who did not provide a valid address. However, our merged dataset allows us to conduct an individual-level analysis of a number of relevant characteristics of those who signed a petition, relative to the registered voters in both within and beyond the city's limits. As our dependent variable is binary-coded 1 if the individual signed an anti-LGBT petition between January and August, 2008, or did not sign a petition (coded 0) - we use logistic regression with robust standard errors to estimate the coefficients of our explanatory variables.

Socio-politically, there are several reasons why individuals might be more likely to sign a ballot petition. With regard to partisan affiliation, previous research on who supports LGBT rights reveals that Republicans and older individuals are less supportive than Democrats and younger individuals (Haider-Markel and Meier 1996; Loftus 2001; Dyck and PearsonMerkowitz 2014; Lewis et al 2017). We operationalize these partisan and age expectations by including dummy variables (coded 1 and 0 ) for individuals registered with the Republican party 
or registered with the Democratic party, leaving No Party Affiliates (NPA) and third party registrants as the reference category, expecting that registered Republicans will be more likely to sign a petition due to its socially conservative nature. ${ }^{2}$

With regard to race and ethnicity and the likelihood of an individual signing a petition, scholars have found that minorities to be generally less supportive of LGBT rights than whites (Rimmerman, Wald, and Wilcox 2000; Haider-Markel and Joslyn 2008; Button, Rienzo, and Wald 1997). Furthermore, Boehmke and Alvarez (2014) find that petition gatherers in California appear to target areas with minority populations. As such, the socially conservative ballot issue may entice blacks and Hispanics to sign the petition at higher rates than whites. However, the substantive nature of the issue-which on its face may lead to greater civic engagement among minorities in the form of petition signing — must be placed within the larger context of political participation among minorities (Rosenstone and Hansen 1993). Further complicating expectations, the leader of the anti-LGBT petition effort in Gainesville, Cain Davis, was African-American. Given Scholzman, Verba, and Brady's (2012) finding that most petition signing takes place within members of the same ethnicity, we expect blacks, and to a lesser degree Hispanics, to be more likely to sign the petition than whites and other ethnicities. We code all African-Americans in the voter file with a dummy variable ( 1 and 0 ), and do the same for Hispanics and those of other races/ethnicities, relegating whites as the reference category.

The substantive nature of the anti-LGBT ballot issue also complicates expectations regarding the likelihood of women and men to sign the petition. Although scholars have found little to no gender gap when it comes to political engagement and participation (Sapiro and Conover 1997; Schlozman, Verba, Brady 2012), men are more likely to oppose LGBT rights than women (Button, Rienzo, and Wald 1997; Loftus 2001; Lewis et al 2017); as such, we might expect men to be more likely to sign a petition to qualify Issue 1 . However, the proponent's campaign to place Issue 1 on the City of Gainesville's ballot heavily targeted women. Indeed, the slogan used by proponents of Issue 1 and their volunteer signature gatherers was, "No Men in Women's Bathrooms."3 As Cain Davis of Citizens for Good Public Policy commented during the ensuing campaign, "We know when men go into women's restrooms, bad things can happen" (AP 2009). As a result, we expect that women (coded 1, with men coded 0 ) to be more likely to sign than men, all else equal.

To operationalize the effect of age on signing the petition, we include in our models every registered voter's age as well as the square of an individual's age, reflecting what we expect

\footnotetext{
2 The signature gathering campaign took place in public areas, parking lots, churches, as well as door-to-door in all areas of the city. We have no reason to suspect that the voluntary signature gathering campaign was sophisticated enough to target Republicans more than independents or third party registrants. Yet, although more than half of registered voters in the City of Gainesville were Democrats during the signature gathering, a slightly higher percentage of registered Republicans signed the petitions. Megan Rolland, “Transgender petition branded 'antigay,” Gainesville Sun, July 23, 2008. Available: http://www.gainesville.com/article/20080723/NEWS/ $\underline{924201154 .}$.

3 For an example of a television ad from the campaign that taps into this fear, refer to Citizens for Good Public Policy, “No Men in Women's Bathrooms”, June 17, 2008. Available: http://www.youtube.com/watch? $\mathrm{v}=\mathrm{ExGBIXKRrYs \& feature=youtu.be}$.
} 
to be a positive-but curvilinear-relationship between increased age and petition signing. Previous studies have found that age is negatively related to support of issues related to transgender protections (Lewis 2017).

We also expect active voters to be more likely to sign the petition. Drawing on the voter file, we are able to determine each registrant's vote history. Although some studies have found that intermittent voters might be more swayed to turn out due to campaign effects (Parry et al. 2008), it is not clear that the same logic applies to who is more likely to sign a ballot petition. We include a dummy variable for regular voters, coded 1 (and 0, otherwise) if an individual voted in the January 31, 2008 presidential preference primary (which also had two city commission elections on the ballot). All else equal, we expect highly engaged Gainesville voters who cast ballots in the 2008 January election are more likely to sign a petition. In addition, we expect core Republican voters-because of ideological opposition to pro-LGBT issues- to be considerably more likely than their Democratic counterparts to sign a petition. As such, after specifying a baseline model, we include interactive terms to capture the higher likelihood of core Republican voters and the decreased likelihood of Democratic core voters signing the petition.

Finally, given the targeting of the signature gathering campaign, we expect registered voters residing in the more affluent, and more homogeneously white northwest part of Gainesville (Ward 2), as well as the racially segregated, predominantly black ward (Ward 1) located in east Gainesville, to be more likely to sign the petition. Ward 3, located in the west and southwest of the city, is inhabited by many University of Florida students, but is more racially and ethnically diverse and less wealthy than Ward 2. We include a dummy variable for each ward, excluding Ward 4, the most heterogeneous and socially liberal ward in the city, as the reference category. Ward 4, coincidentally, housed the "headquarters" of the signature gathering effort for Issue 1, which was temporarily set up in a vacant lot. As individuals who live in neighborhoods with reinforcing political structures might be more likely to sign a petition than those living in an area with cross-pressures (see Huckfeldt and Sprague 1995), we expect registered voters living in the more socially conservative wards to be more likely to signed the petition.

In addition to determining who signed a petition, we are also interested in who was more likely to have signed a valid (or invalid) petition, as determined by the Alachua County Canvassing Board. Drawing from our dataset of submitted signatures (both valid and invalid), we examine predictors of two more dependent variables: those who signed valid petitions and those who signed multiple petitions. In addition to 6,379 valid petitions, our dataset of 8,747 submitted petitions includes 238 duplicate signatures, the names of 1,061 individuals residing in Alachua County but not in the City of Gainesville, and hundreds of other rejected petitions, as determined by a three-member Alachua County Canvassing Board. We are able to link the voter file the registration numbers of 6,307 of the 8,747 individuals who signed petitions, providing us the signer's name, address, age, political party, vote history, and sociodemographic information. In particular, we are interested if those who signed on a Sunday were more likely to have their petition validated by the canvassing board. The campaign to place Issue 1 on the 
ballot explicitly targeted churches during the signature gathering effort. ${ }^{4}$ As one of the coalition leaders, Pastor George Brantley, told City of Gainesville Commissioners as they prepared to vote for the ordinance, "You are trying to operate in a realm you do not have the authority to operate in."

Controlling for same set of independent predictors used in determining the likelihood of someone signing a petition, given both the ideological and prosocial motivations for signing a petition, we expect Republicans as well as individuals who signed a petition on a Sunday to be more likely to have valid signatures. However, it is possible that some individuals who supported the anti-LGBT measure signed multiple petitions, perhaps due to ideological exuberance, in particular women, due to the targeted campaign that focused on "men in women's bathrooms."

\section{Results}

Table 1 reports the logit results predicting who signed the 2008 Gainesville anti-LGBT ballot initiative. Our base model (Table 1, Model A), excludes vote history and includes all 63,967 registered voters in the City of Gainesville voter file as of August 1, 2008.5 Nearly all of the independent variables are significant, with their coefficients are in the predicted direction. As expected, relative to those registered as non-partisans or with third parties, registered Republicans were more likely and registered Democrats less likely to have signed an initiative petition overturning the city's LGBT protections. Older registered voters-up to a point-were more likely as well to sign, as were women, all else equal. Model A also reveals that registered Hispanics were no more likely than white registered voters to have signed. Blacks, on the other hand, were more likely than whites to sign petitions, confirming our expectation that the socially conservative substance of the issue likely influenced some blacks to sign the petition. Finally, we find that compared to residents living in the more socially liberal and racially mixed Ward 4, registered voters in the city's other three wards were more likely to have signed a petition.

Since coefficients in logit models are difficult to interpret, we convert them into the expected values (probabilities) of signing a petition. The marginal effects $(\mathrm{mfx})$ reveal the change in probability produced by increasing one variable while the others are held at their mean values. On average, a registered voter in the city had a 7 percentage point likelihood of signing an Issue 1 petition. Older registered voters were more likely to sign a petition, although we find the likelihood of civic engagement, as expected, tapers off in old age. The probability of signing a petition increases by roughly .07 percentage points with every additional 10 years of

${ }^{4}$ For an example of a television ad from the campaign that appealed directly to religious citizens in Gainesville, see Citizens for Good Public Policy, "Petition Drives," June 13, 2008. Available: http://www.youtube.com/watch? $\mathrm{v}=S \mathrm{Go} 65 \mathrm{I} 0 \mathrm{~K} 9 \mathrm{p} 0 \& \mathrm{NR}=1$.

5 A limitation of our dataset is that the Alachua County voter file does not include the vote history of the nearly 14,000 voters who newly registered in the county between the January 31, 2008 presidential preference primary and the August 1, 2008 cutoff date for petitions to be submitted. We deal with this limitation by presenting the results of two separate models of the likelihood of signing a petition, with and without the vote history measure. Alternative models, in which we substitute voting (or not voting) in the 2008 presidential primary, the 2008 August primary, and the 2008 General Election do not alter the findings; those who voted in all three previous elections were more likely to sign a petition than those who voted in two of the previous three elections, and so on. 
Table 1: Probability of Signing an Issue 1 Petition

\begin{tabular}{|c|c|c|c|c|c|c|c|c|c|}
\hline & \multicolumn{3}{|c|}{ Model A: Base Model } & \multicolumn{3}{|c|}{ Model B: Vote history } & \multicolumn{3}{|c|}{$\begin{array}{l}\text { Model C: Vote history with } \\
\text { Interactions }\end{array}$} \\
\hline & Coef. & P-value & $\mathrm{mfx}$ & Coef. & $\mathrm{P}$-value & $\mathrm{mfx}$ & Coef. & P-value & $\mathrm{mfx}$ \\
\hline Age & $\begin{array}{r}.103 \\
(.004)\end{array}$ & .000 & $\begin{array}{r}.007 \\
(.000)\end{array}$ & $\begin{array}{r}.076 \\
(.004)\end{array}$ & .000 & $\begin{array}{r}.006 \\
(.000)\end{array}$ & $\begin{array}{r}.077 \\
(.004)\end{array}$ & .000 & $\begin{array}{r}.007 \\
(.000)\end{array}$ \\
\hline $\mathrm{Age}^{2}$ & $\begin{array}{r}-.001 \\
(.000)\end{array}$ & .000 & $\begin{array}{r}-.000 \\
(.000)\end{array}$ & $\begin{array}{r}-.001 \\
(.000)\end{array}$ & .000 & $\begin{array}{r}-.000 \\
(.000)\end{array}$ & $\begin{array}{r}-.001 \\
(.000)\end{array}$ & .000 & $\begin{array}{r}-.000 \\
(.000)\end{array}$ \\
\hline Female & $\begin{array}{r}.256 \\
(.028)\end{array}$ & .000 & $\begin{array}{r}.017 \\
(.002)\end{array}$ & $\begin{array}{r}.260 \\
(.029)\end{array}$ & .000 & $\begin{array}{r}.022 \\
(.002) \\
\end{array}$ & $\begin{array}{r}.262 \\
(.030) \\
\end{array}$ & .000 & $\begin{array}{r}.022 \\
(.003)\end{array}$ \\
\hline Hispanic & $\begin{array}{r}.037 \\
(.073)\end{array}$ & .612 & -- & $\begin{array}{r}.151 \\
(.080)\end{array}$ & .058 & $\begin{array}{r}.014 \\
(.008)\end{array}$ & $\begin{array}{r}.153 \\
(.080)\end{array}$ & .055 & $\begin{array}{r}.014 \\
(.008)\end{array}$ \\
\hline Black & $\begin{array}{r}.733 \\
(.040)\end{array}$ & .000 & $\begin{array}{r}.059 \\
(.004)\end{array}$ & $\begin{array}{r}.842 \\
(.043)\end{array}$ & .000 & $\begin{array}{r}.089 \\
(.005)\end{array}$ & $\begin{array}{r}.815 \\
(.043)\end{array}$ & .000 & $\begin{array}{r}.086 \\
(.005)\end{array}$ \\
\hline Other Race & $\begin{array}{r}.012 \\
(.077)\end{array}$ & .872 & -- & $\begin{array}{r}.049 \\
(.081)\end{array}$ & .548 & --- & $\begin{array}{r}.046 \\
(.081)\end{array}$ & .571 & --- \\
\hline Democrat & $\begin{array}{r}-.074 \\
(.044)\end{array}$ & .091 & $\begin{array}{r}-.004 \\
(.003)\end{array}$ & $\begin{array}{r}-.281 \\
(.047)\end{array}$ & .000 & $\begin{array}{r}-.025 \\
(.024)\end{array}$ & $\begin{array}{r}-.184 \\
(.060)\end{array}$ & .002 & $\begin{array}{l}-.016 \\
(.005)\end{array}$ \\
\hline Republican & $\begin{array}{r}.903 \\
(.046)\end{array}$ & .000 & $\begin{array}{r}.075 \\
(.005)\end{array}$ & $\begin{array}{r}.747 \\
(.048)\end{array}$ & .000 & $\begin{array}{r}.076 \\
(.006)\end{array}$ & $\begin{array}{r}.518 \\
(.068)\end{array}$ & .000 & $\begin{array}{r}.050 \\
(.007)\end{array}$ \\
\hline Ward 1 & $\begin{array}{r}.541 \\
(.056)\end{array}$ & .000 & $\begin{array}{r}.041 \\
(.005)\end{array}$ & $\begin{array}{r}.512 \\
(.059)\end{array}$ & .000 & $\begin{array}{r}.049 \\
(.006)\end{array}$ & $\begin{array}{r}.503 \\
(.059)\end{array}$ & .000 & $\begin{array}{r}.049 \\
(.006)\end{array}$ \\
\hline Ward 2 & $\begin{array}{r}.842 \\
(.050)\end{array}$ & .000 & $\begin{array}{r}.066 \\
(.004)\end{array}$ & $\begin{array}{r}.743 \\
(.051)\end{array}$ & .000 & $\begin{array}{r}.071 \\
(.005)\end{array}$ & $\begin{array}{r}.741 \\
(.051)\end{array}$ & .000 & $\begin{array}{r}.071 \\
(.005)\end{array}$ \\
\hline Ward 3 & $\begin{array}{r}.302 \\
(.052)\end{array}$ & .000 & $\begin{array}{r}.021 \\
(.004)\end{array}$ & $\begin{array}{r}.299 \\
(.055)\end{array}$ & .000 & $\begin{array}{r}.027 \\
(.005)\end{array}$ & $\begin{array}{r}.296 \\
(.055)\end{array}$ & .000 & $\begin{array}{r}.027 \\
(.005)\end{array}$ \\
\hline Regular Voter & & & & $\begin{array}{r}.642 \\
(.032)\end{array}$ & .000 & $\begin{array}{r}.056 \\
(.003)\end{array}$ & $\begin{array}{r}.588 \\
(.086)\end{array}$ & .000 & $\begin{array}{r}.052 \\
(.008)\end{array}$ \\
\hline $\begin{array}{l}\text { Democratic } \\
\text { Regular Voter }\end{array}$ & & & & & & & $\begin{array}{r}-.118 \\
(.094)\end{array}$ & .211 & --- \\
\hline $\begin{array}{l}\text { Republican } \\
\text { Regular Voter }\end{array}$ & & & & & & & $\begin{array}{r}.356 \\
(.102) \\
\end{array}$ & .000 & $\begin{array}{r}.034 \\
(.011)\end{array}$ \\
\hline Constant & $\begin{array}{r}-6.234 \\
(.108)\end{array}$ & .000 & & $\begin{array}{l}5.485 \\
(.119)\end{array}$ & .000 & & $\begin{array}{r}-5.480 \\
(.121)\end{array}$ & .000 & \\
\hline Pseudo R2 & & & .108 & & & .093 & & & .094 \\
\hline Log pseudo & & & 8355.986 & & & 589.967 & & -16 & 565.428 \\
\hline Wald chi2 & 4211.35 & .000 & & 3136.16 & .000 & & 3278.81 & .000 & \\
\hline $\mathrm{N}$ & & & 63,967 & & & 49,793 & & & 49,793 \\
\hline $\begin{array}{l}\text { Note: Unstand } \\
\text { Non-Hispanic }\end{array}$ & $\begin{array}{l}\text { zed log } \\
\text { ite, No }\end{array}$ & $\begin{array}{l}\text { tic regre } \\
\text { arty Affi }\end{array}$ & $\begin{array}{l}\text { coeffi } \\
\text { on }(\mathrm{N})\end{array}$ & $\begin{array}{l}\text { ts repo } \\
\text { and th }\end{array}$ & $\begin{array}{l}\text { ted, with } \\
\text { d party, a }\end{array}$ & $\begin{array}{l}\text { ist sta } \\
\text { esiden }\end{array}$ & $\begin{array}{l}\text { d errors } \\
\text { Ward } 4\end{array}$ & $\begin{array}{l}\text { orenth } \\
\text { omitte }\end{array}$ & \\
\hline
\end{tabular}


life, all else equal. We find that women were nearly 2 percentage points more likely than men to sign, ceteris paribus. In keeping with the conservative nature of the Issue 1 campaign, registered Republicans were significantly more likely ( 7.5 percentage points) and Democrats slightly less likely to sign a petition than those registered as NPAs or with third parties. Blacks were 6 percentage points more likely to have signed, but Hispanics and members of other racial and ethnic groups were no more or less likely to have signed, relative to whites. Despite the petition drive's headquarters in Ward 4, registered voters living in the other three wards were more likely to sign a petition than those living in Gainesville's most liberal ward; registered voters residing in Ward 1 were 4.1 percentage points more likely, those in Ward 2 were 6.6 percentage points more likely, and those in Ward 3 were 2.1 percentage points more likely to sign, holding all other variables at their mean values.

Our second, expanded model (Table 1, Model B), adds vote history-specifically, whether or a registered voter cast a ballot in the January 29, 2008 presidential preference primary (which also contained a statewide referendum and three city council races). When including the vote history proxy in our model, the sample size decreases by 14,174 due to the influx of newly registered voters in the city between January 1, and August 1,2008, with no vote history. The overall results of the expanded model are nearly identical to those of the base model. Vote history is a significant and positive predictor of whether a registered voter signed an Issue 1 petition. The marginal effects show that having voted in the primary increased the chances of a registered voter in Gainesville signing a petition by 5.6 percentage points, all other variables held at their mean values. With the inclusion of vote history, Democratic registrants become 2.5 percentage points less likely, and Hispanics 1.5 percentage points more likely, to sign a petition.

Table 1, Model C, includes two interaction terms that combine Democratic or Republican party registration with vote history. Here we are interested in whether partisanship and being a regular voter work together to promote or discourage signing a ballot petition. Leading credence to the robustness of the other two models, the substantive results of Model C are virtually identical to those of the previous models. The interaction between Republican registration and vote history is significant and positive; as the marginal effects reveal, Republican core voters were 3.4 percentage points more likely to sign a petition than NPAs and third party registrants. However, we find that the interactive term for Democratic regular voters, while in the expected negative direction, fails to reach conventional levels of statistical significance. In sum, across all three model specifications, our findings remain robust. Older voters, women, African-Americans, Hispanics, Republicans, regular voters, and those residing outside Ward 4 were all more likely to have signed an Issue 1 petition, holding constant the other factors.

Simulating the likelihood of various hypothetical individuals registered to vote in Gainesville can help to illustrate our major findings. Drawing from the fully specified Model C, we find that the median registered voter in Gainesville-a 42 year old white female Democrat residing in Ward 4 and who did not vote in January 2008 primary had only a 4 percent likelihood of signing an Issue 1 petition. By way of contrast, a Republican white female regular voter living in Ward 2 who voted in the January primary had a 37 percent likelihood of signing a 
petition-better than a one in three chance. However, an identical middle-aged white female Republican registered in Ward 2 who did not vote in the January primary had only a 19 percent probability of signing, roughly half the chance if she was not a regular voter. These hypothetical registered voters reflect the overall findings of our three models: that older, female, Republican, active voters residing in the city's three more racially homogenous wards had a much greater chance of signing a petition than other residents.

As we reported earlier when discussing the full model, given the socially conservative nature of the petition drive, a registered voter's race is a significant predictor of whether an individual signed a petition, as is a registered voter's prior political participation. What is interesting, though, is that African-American women-a primary target of the petitioners soliciting signatures for Issue 1 - who were habitual voters, were much less likely to have signed a petition. For example, a hypothetical 45 year old black female Democrat residing in the city's predominately black Ward 1, who did not cast a ballot in the January primary, had a 17 percent chance of signing an anti-LGBT petition. In sharp contrast, however, an identical hypothetical black female regular voter had only an 8 percent likelihood of signing. This finding suggests that African-American women who were registered to vote in the city and politically engaged (as evidenced as voting in the presidential preference primary, which had Democratic presidential candidates Barack Obama and Hillary Clinton on the ballot), may have received partisan signals from the local Democratic party and its allies to shun the anti-gay ballot petition signature drive. At a minimum, the simulations suggest that signing a petition may be attenuated by other factors, such as race and prior political participation.

In addition to assessing who was more likely to sign a petition, we are interested in who was more likely to sign a valid or duplicate Issue 1 petition. Our universe of 6,307 individuals who signed a petition is limited to those individuals registered to vote in Alachua County whom the Supervisor of Elections was able to match with the voter rolls. This includes otherwise valid signatures by individuals registered in the county but not in the City of Gainesville, illegible signatures or incorrect or missing information on a petition of a registered Gainesville voter that caused the petition to be invalidated because it did not match the voter file, and otherwise valid signatures that were rejected because they were duplicates. To model the likelihood of an individual signing a valid petition or signing more than one petition we use the same set of independent variables as in Table 1, Model A, except we do not control for the Ward in which the registered voter resides. Instead, we cluster the models by the county's 71 precincts in order to more precisely control for any possible targeting by signature gatherers inside the city.

We also include a dummy variable denoting if an individual signed a petition on a Sunday, with the expectation that Sunday signers were more likely to sign a valid petition, following the theory that they may have been encouraged to sign by people they knew, such as signing at church. 6 Those signing multiple petitions may have done so because they were motivated by ideological or prosocial rationales, or alternatively, out of ignorance. For example, an individual may have signed a petition more than once because she had forgotten she had

${ }^{6}$ We ran a number of models (not shown) with alternative specifications, including an ordinal measure of the number of days before the petition filing deadline; none altered the substantive findings of the models we present. 
signed a petition two months earlier, or because she was highly motivated to see the measure qualify for the ballot.

The first model in Table 2 reports the likelihood of a registered voter signing a valid petition. We find that Sunday signers were much more likely to sign a valid petition than other Gainesville registered voters, holding constant other variables. Both Sunday signers and regular voters were significantly more likely to sign a valid petition, but black registered voters who signed a petition were considerably less likely than white registered voters who signed a petition to have their signature validated, all else equal. Perhaps surprisingly, gender, age, and party registration did not affect the likelihood of signing a valid petition. In short, the findings complicate the robust participation rates we found of black and Hispanics with regard to who signs petition; though they were more likely to sign a petition, black signers were more likely to have their signatures rejected by the canvassing board.

The second model in Table 2 explores the probability of an individual signing an Issue 1 petition multiple times. We find that registered women who signed a petition were significantly more likely than men to sign a petition more than once, all else equal. Although women were significantly more likely to sign an Issue 1 petition (as shown in Table 1 ), it is difficult to discern any single reason why they may have been more likely to sign multiple petitions. Prosocial, ideological, or even ignorance may all be feasible rationales.

Table 2: Probability of Signing a Valid, Duplicate, or Invalid Petition

\begin{tabular}{|c|c|c|c|c|c|c|}
\hline & \multicolumn{3}{|c|}{ Signing a Valid Petition } & \multicolumn{3}{|c|}{$\begin{array}{l}\text { Signing a Duplicate } \\
\text { Petition }\end{array}$} \\
\hline & Coef. & $\mathrm{P}$-value & Mfx & Coef. & $\begin{array}{l}\text { P- } \\
\text { value }\end{array}$ & $\mathrm{mfx}$ \\
\hline Age & $\begin{array}{r}.027 \\
(.016)\end{array}$ & .096 & -- & $\begin{array}{r}.042 \\
(.023)\end{array}$ & .068 & -- \\
\hline $\mathrm{Age}^{2}$ & $\begin{array}{r}-.000 \\
(.000)\end{array}$ & .219 & --- & $\begin{array}{r}.000 \\
(.000)\end{array}$ & .171 & -- \\
\hline Female & $\begin{array}{r}-.021 \\
(.094)\end{array}$ & .822 & -- & $\begin{array}{r}.318 \\
(.154)\end{array}$ & .039 & $\begin{array}{r}.010 \\
(.005)\end{array}$ \\
\hline Hispanic & $\begin{array}{r}-.421 \\
(.231)\end{array}$ & .067 & --- & $\begin{array}{r}.211 \\
(.330)\end{array}$ & .522 & -- \\
\hline Black & $\begin{array}{r}-.474 \\
(.087)\end{array}$ & .000 & $\begin{array}{r}-.037 \\
(.007)\end{array}$ & $\begin{array}{r}.257 \\
(.170)\end{array}$ & .130 & $\ldots$ \\
\hline Other Race & $\begin{array}{r}-.257 \\
(.221)\end{array}$ & .223 & -- & $\begin{array}{r}-.401 \\
(.450)\end{array}$ & .373 & -- \\
\hline Democrat & $\begin{array}{r}.137 \\
(.141)\end{array}$ & .332 & --- & $\begin{array}{r}-.127 \\
(.249)\end{array}$ & .609 & -- \\
\hline Republican & $\begin{array}{r}.023 \\
(.143)\end{array}$ & .870 & --- & $\begin{array}{r}.257 \\
(.223)\end{array}$ & .250 & -- \\
\hline Regular Voter & $\begin{array}{r}.290 \\
(.105)\end{array}$ & .006 & $\begin{array}{r}.021 \\
(.008)\end{array}$ & $\begin{array}{r}.173 \\
(.166)\end{array}$ & .299 &.-- \\
\hline $\begin{array}{l}\text { Signed on } \\
\text { Sunday }\end{array}$ & $\begin{array}{r}.463 \\
(.193)\end{array}$ & .016 & $\begin{array}{r}.030 \\
(.010)\end{array}$ & $\begin{array}{r}-.359 \\
(.271)\end{array}$ & .186 &.-- \\
\hline Constant & $\begin{array}{r}1.52 \\
(.425)\end{array}$ & .000 & & $\begin{array}{r}-4.920 \\
(.638)\end{array}$ & .000 & \\
\hline Pseudo R2 & & & .0196 & & & .013 \\
\hline Log pseudo & & & 734.427 & & & -954.015 \\
\hline Wald chi2 & 118.55 & .000 & & 35.49 & .000 & \\
\hline $\mathrm{N}$ & & & 6,307 & & & 6,307 \\
\hline $\begin{array}{l}\text { Note: Unstand } \\
\text { errors in parent } \\
\text { Affiliation (NP }\end{array}$ & $\begin{array}{l}\text { d logistic reg } \\
\text { clustered by } \\
\text { d third party }\end{array}$ & $\begin{array}{l}\text { ression coef } \\
\text { precinct. N } \\
\text { are omitted }\end{array}$ & $\begin{array}{l}\text { ficients rep } \\
\text { on-Hispan } \\
\text { as referenc }\end{array}$ & $\begin{array}{l}\text { orted, with r } \\
\text { ic White and } \\
\text { ce categories. }\end{array}$ & $\begin{array}{l}\text { obust stan } \\
\text { No Party }\end{array}$ & \\
\hline
\end{tabular}




\section{Georeferencing Good and Bad Petition Signatures}

In order to augment our statistical findings, we use GIS analysis to provide a bird's eye view of where the valid and invalid petitions signatures were collected. We geocoded the home addresses of all the individuals who signed a petition, as well as the home addresses of all the registered voters in the county; that is, we took the addresses of the signers and linked them to geographic coordinates, which allowed us to locate the addresses on a map. ${ }^{7}$ The GIS analysis gives a detailed spatial look at the density and distribution of good and bad signatures.

\section{Valid Signatures}

The density of valid petition signatures across Gainesville is shown in Figure 1, with red signifying the densest regions and green the least dense, with the yellow regions of the city somewhere in between the two extremes. Only registered voters in Gainesville could sign a valid petition, so we crop the map to the city limits, clipping a couple sparsely populated northern and eastern "arms" for visual reasons. The highest density area of valid signatures was in the northwestern portion of the city, followed by the eastern, as was found in our ward-level statistical analysis. As indicated previously, northwest Gainesville is a more conservative, relatively older section of the city, while the eastern portion is largely African-American. By controlling for the density of all the registered voters in the county, we spatially assess the proportion of registered voters residing in Gainesville who signed a valid petition.

Figure 1 displays the proportion of registered voters who signed a valid petition, revealing that conservative northwest Gainesville, as well as heavily African-American east Gainesville, were especially rich targets for signatures by the petition campaign. The UF campus community, located in the southcentral part of the city, becomes notable for the opposite reason: very few of the registered voters on campus - nearly all UF students-signed a petition. Though these results are not a surprise-not only are younger voters generally less politically active, but they also tend to be more liberal and advocate for gay rights-Figure 1 conforms the empirical models, giving more specificity to which younger registered voters did not sign a petition.

\footnotetext{
7 The US Census Bureau provides a set of files for the country called "edges" maps. These geographic shapefiles mark rivers, the outlines of lakes, and more relevantly, streets, along with address information for those streets. Thus, using ArcGIS, a geocoder can be easily produced to help "automatically" match most of the addresses found on the petitions. Of the 7,991 signatures that listed an address in Alachua County, about $92 \%$ were matched through this Census-provided geocoder, and the remaining $8 \%$ were geocoded by hand; many of the misses were from students living in University of Florida dorms, which do not use formal street addresses, but could be linked to locations using a campus map as a reference.
} 
Figure 1: Proportion of Registered Voters Signing Valid Petitions

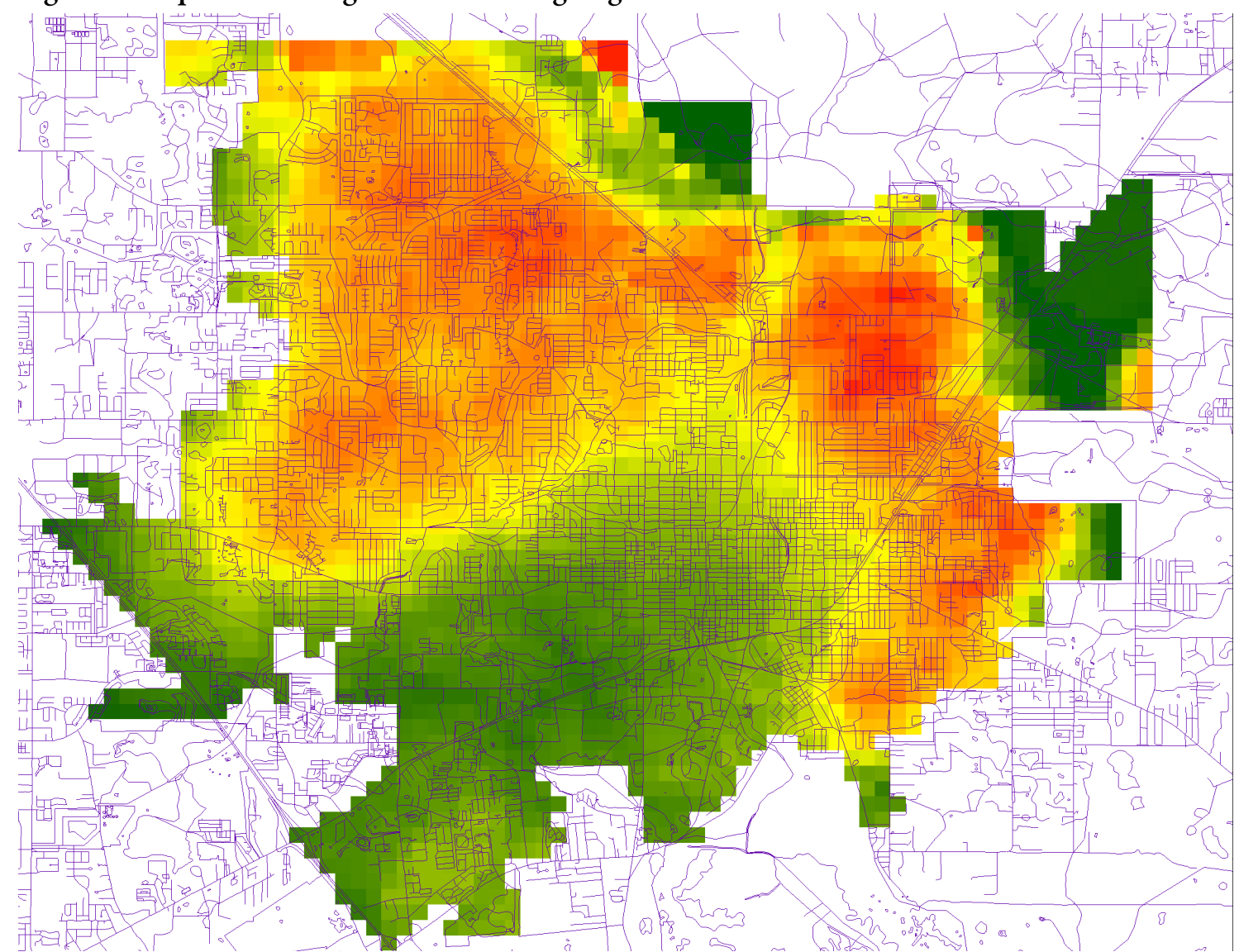

Note: Density of valid petition signatures across Gainesville. Red signifies the most dense, yellow somewhat less dense, and green the least dense regions of the city where valid signatures were collected.

\section{Invalid Signatures}

Our GIS analysis allows us also to reveal spatially the residencies of registered voters who improperly signed petitions to challenge the city ordinance. Figure 2 is a density map of all of the invalid petitions signed by voters registered in Alachua County, including those living outside the city's boundaries. As Figure 2 shows, most of the invalid signatures (65.8\%) on the submitted petitions were by registered voters living in Alachua County but who resided outside Gainesville's city limits (outlined in black on the map), in particular, by those living in neighborhoods immediately adjacent to the city's boundaries. The most likely explanation is regardless of motivation, most of these signers were simply not aware that they did not live in the city; indeed, the majority of these registered voters who signed invalid petitions actually have Gainesville mailing addresses, although technically they reside beyond the city's limits. While city and county borders are a jurisdictional reality, they are often not divisions in an everyday, practical sense (Peterson 1981). The spate of invalid signatures in northwestern Gainesville is likely is the result of an especially confusing patchwork of annexations over the years by the City of Gainesville. 
Figure 2: Density of Invalid Petitions Signed by Alachua County Registered Voters

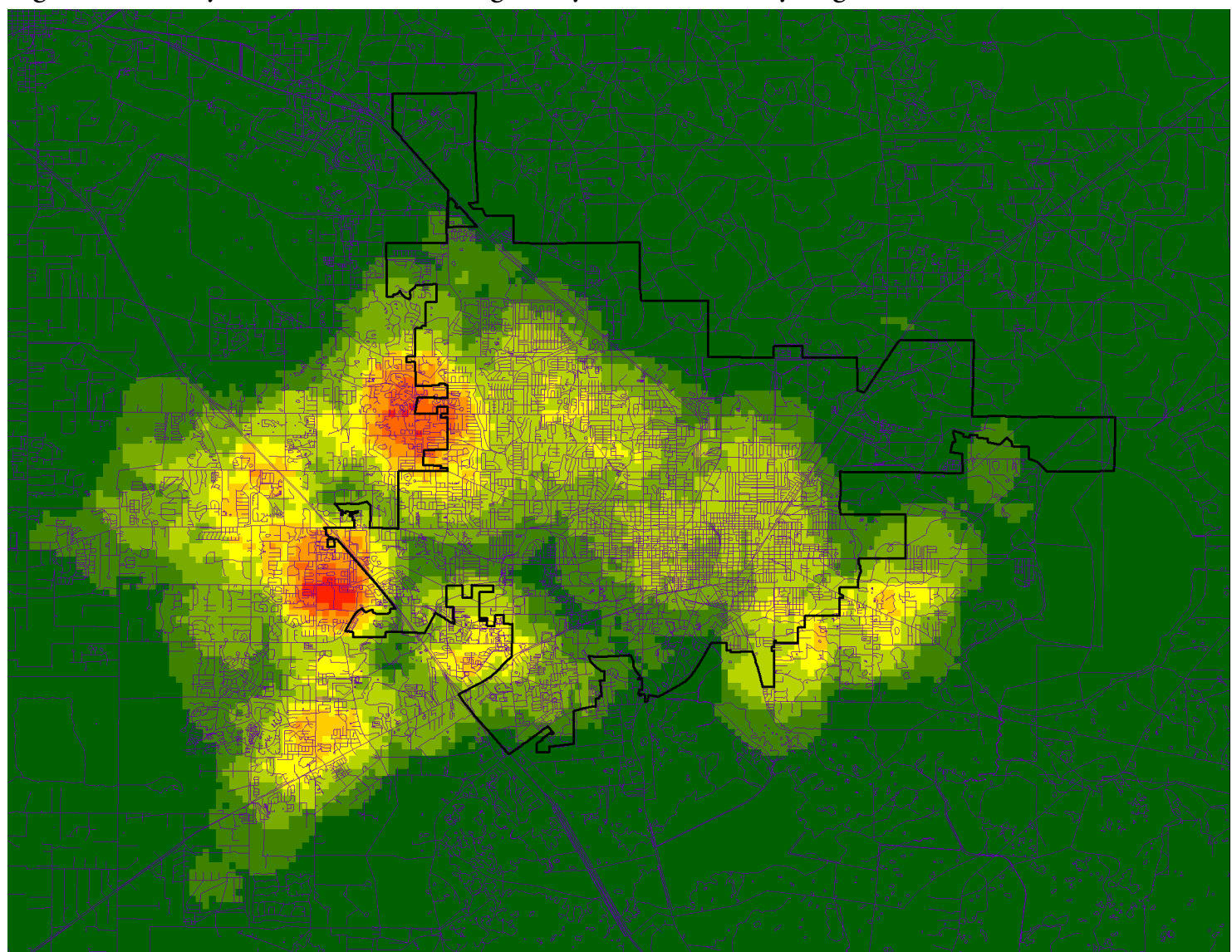

Note: Density of invalid petition signatures across Alachua County. Gainesville's city limits are outlined with a solid black line. Red signifies the most dense, yellow somewhat less dense, and green the least dense regions of the county where invalid signatures were collected.

\section{Conclusion}

The process of direct democracy has received considerable scholarly attention in recent years.

There are numerous studies examining the indirect effects that the process of direct democracy has on citizen engagement. Yet, as a form of participation, few studies have assessed using individual-level data whether the act of signing a ballot petition broadens the sociopolitical scope of participation (Rosenstone and Hansen 1993; Schlozman, Verba, and Brady 2012). To date there is little scholarship on petition gathering (Nall, Schneer, and Carpenter 2018), and even less on whether signing a ballot petition may provide citizens with ideological or civic gratification and the opportunity to promote a desired collective outcome. Boehmke and Alvarez (2014: 9) call for more studies to investigate ballot initiative signature collection in more detail so as to "allow a more comprehensive understanding of who signs petitions, how that act relates to political participation and trust, and how the two processes together influence representation, both in terms of the issues that voters must decide on election day and the $<$ composition of the electorate that decides them." Their county-level study of eight initiatives that qualified for the ballot in California a decade ago provides preliminary insight into who may be more likely to be asked to sign, but it relies on aggregate-level data and raises the 
possibility of an ecological inference fallacy when trying to establish who actually signs ballot petitions and whether their signatures are valid.

A key finding of our analysis of the anti-LGBT Issue 1 signature gathering campaign in Gainesville, Florida, is that the petition-gathering effort was able to foster participation among alternative groups who are less likely to participate in more typical forms of political activity, such as making political contributions or turning out to vote. In all three of the full logit model specifications gauging sociopolitical involvement, we find African-Americans to be significantly more likely to sign an Issue 1 petition than whites. The backers of Issue 1 certainly tried to target blacks due to the perception that they are more socially conservative on the issue of LGBT rights. As such, depending on the substantive nature of a petition, our study provides evidence that individuals who might not otherwise be expected to participate may become politically engaged when asked to sign a petition. Indeed, signing a petition, as others have shown (Parry, Smith, and Henry 2012), may mobilize individuals to turn out to vote in a subsequent election, even those who are only occasional voters.

The findings from our GIS analysis support the spatial distribution of those who signed valid (and invalid) petitions. An important caveat of the GIS analysis should be reiterated. Even though northwest and east Gainesville consistently stand out in the GIS analyses in the expected directions, interpreting the results to be a product of African-Americans in the east or white conservatives in northwest Gainesville could be ecologically fallacious. The same, however, is not true of those registered voters in south central Gainesville living on the campus of the University of Florida; by definition, they are UF students. Because UF restricts residency on its campus to its students, the GIS analysis provides additional information about the registered voters in the county who signed (or did not sign) a valid (or invalid) petition. The GIS analysis reveals that few UF students who were registered to vote in Alachua County and who lived on campus signed a petition to overturn the city ordinance protecting the LGBT community. The GIS analysis largely supports the findings in our logit models. In particular, east Gainesville-with its largely African-American population-stands out as a hot-bed of prosigning activity.

Our study has some limitations. Our data do not allow us to answer the question of whether northwest or eastside residents in the city were more likely to support anti-gay causes, or if they simply were those who were asked by petition circulators to sign petitions. The data necessary to answer this question - not only who was approached to sign a petition, but who chose to sign or not to sign-is difficult to collect (Donovan and Smith 2008). Our study is unable to determine whether those who signed a petition had a strong opinion on the issue, or alternatively, if they signed petitions without fully understanding what they were signing. In addition, our study is limited by how generalizable the findings might be to other initiative campaigns, within the city of Gainesville or beyond. Would a morally liberal campaign in Gainesville find an inverse distribution of signers, or would northwest Gainesville again stand out simply because it is more politically active? Would a different morally conservative campaign find more support from the UF community if it spent time on campus trying to collect signatures? Our empirical models, supplemented by the GIS maps, give strong evidence that geography does matter in petition signing - not only with regard to valid signatures, but 
also the source of invalid signatures. Future research is needed, however, to determine exactly how and why it matters.

Finally, our study is limited by the fact that there exists very little theory to generate expectations at the individual level for why some individuals might be more likely to voluntarily submit personal information to signature gatherers than others. More research needs to be conducted in this area, especially since so much is riding on the process of direct democracy. Millions of dollars are spent every election cycle by proponents collecting ballot measure signatures and by their opponents who challenge the veracity of the submitted signatures. From these theoretical and material perspectives, then, our research should be of interest to both academics and to practitioners. Yet the lack of empirical research on who signs ballot petitions has not prevented the United State Supreme Court from ruling on the topic. Notable U.S. Supreme Court decisions-Buckley v. The American Constitutional Law Foundation (1999), Meyer v. Grant (1988), and Doe v. Reed (2010) - have all dealt with First Amendment issues related to signature gathering, and all of them reached the high court with limited empirical evidence on the sociopolitical dimensions of signature gathering (Smith 2012). Our analysis provides a first step towards advancing a deeper knowledge of not only who signs petitions, but also of who signs valid and invalid petitions, and should be of interest to practitioners as well as scholars probing questions of civic engagement. 


\section{Bibliography}

Associated Press. 2009. "Florida Conservatives Fight for Repeal of Transgender Restroom Rule." January 10, 2009. Available at http://www.foxnews.com/story/ 0,2933,478924,00.html\#ixzz1 MMLzn0eA.

Boehmke, Frederick J. and R. Michael Alvarez. 2014. "Where the good signatures are: Signature collection and initiative qualification in California," Social Science Journal 52: 248-57.

Bowler, Shaun, Todd Donovan, and Caroline Tolbert, eds. 1998. Citizens as Legislators: Direct Democracy in the United States. Columbus: Ohio State University Press.

Broder, David S. 2000. Democracy Derailed: Initiative Campaigns and the Power of Money. New York, NY: Harvest.

Burnett, Craig M. and Vladimir Kogan. 2015. “When Does Ballot Language Influence Voter Choices? Evidence from a Survey Experiment," Political Communication 32: 109-126.

Burnett, Craig M. and Janine A. Parry. 2014. "Gubernatorial Endorsements and Ballot Measure Approval," State Politics and Policy Quarterly 14: 178-195.

Button, James W., Barbara A. Rienzo and Kenneth D. Wald. 1997. Private Lives, Public Conflicts: Battles Over Gay Rights in American Communities. Washington, DC: Congressional Quarterly Press.

Donovan, Todd and Daniel A Smith. 2008. "Identifying and Preventing Signature Fraud on Ballot Measure Petitions." In Election Fraud: Detecting and Deterring Electoral Manipulation, eds. R. Michael Alvarez, Thad E. Hall, and Susan D. Hyde. Washington, DC: Brookings Institution Press.

Donovan, Todd, Caroline Tolbert, and Daniel A. Smith. 2009. "Political Engagement, Mobilization and Direct Democracy." Public Opinion Quarterly 73: 98-118.

Dyck, Joshua J. and Pearson-Merkowitz. 2014. “To Know You Is Not Necessarily to Love You: The Partisan Mediators of Intergroup Contact," Political Behavior 36: 553-80.

Dyck, Joshua J. and Nicholas R. Seabrook. 2010. "Mobilized by Direct Democracy: Short-Term Versus Long-Term Effects and the Geography of Turnout in Ballot," Social Science Quarterly 91: 188-208.

Haider-Markel, Donald P., and Mark Joslyn. 2008. "Understanding Beliefs about the Origins of Homosexuality and Subsequent Support for Gay Rights An Empirical Test of Attribution Theory." Public Opinion Quarterly 72: 291-310.

Haider-Markel, Donald P., and Kenneth J. Meier. 1996. "The Politics of Gay and Lesbian Rights: Expanding the Scope of the Conflict." The Journal of Politics 58: 332-49.

Helson, Harry, Robert R. Blake, and Jane Srygley Mouton. 1956. "Petition-Signing as Adjustment to Situational and Personal Factors." Journal of Social Psychology 48: 3-10.

Huckfeldt, Robert and John Sprague. 1995. Citizens, Politics, and Social Communication: Information and Influence in an Election Campaign. New York: Cambridge University Press.

Schlozman, Kay Lehman, Sidney Verba, and Henry E. Brady. 2012. The Unheavenly Chorus: Unequal Political Voice and the Broken Promise of American Democracy. Princeton: Princeton University Press.

Loftus, Jeni. 2001. "America’s Liberalization in Attitudes toward Homosexuality, 1973 to 1998." American Sociological Review 66: 762-782.

Lewis, Daniel C., et al. 2017. "Degrees of Acceptance: Variation in Public Attitudes toward Segments of the LBT Community," Political Research Quarterly 70: 861-75. 
Lupia, Arthur. 1994. "Shortcuts versus Encyclopedias: Information and Voting Behavior in California Insurance Reform Elections." American Political Science Review 88: 63-76.

Magleby, David. 1984. Direct Legislation: Voting on Ballot Propositions in the United States. Baltimore: Johns Hopkins University Press.

Magleby, David and Kelly Patterson. 1998. "Consultants and Direct Democracy." PS: Political Science and Politics 31: 160-164.

Matsusaka, John G. 2004. For the Many or the Few: The Initiative, Public Policy, and American Democracy. Chicago: University of Chicago Press.

Nall, Clayton, Benjamin Schneer, and Daniel Carpenter. 2018. "Paths of Recruitment: Rational Social Prospecting in Petition Canvassing," American Journal of Political Science 62: 192-209.

Nieman, Max, and M. Gottdiener. 1982. "The Relevance of the Qualifying Stage of Initiative Politics: The Case of Petition Signing." Social Science Quarterly 63: 582-588.

Parry, Janine A., et al. "Mobilizing the Seldom Voter: Campaign Contact and Effects in HighProfile Elections," Political Behavior 30: 97-113.

Parry, Janine A., Daniel A. Smith, and Shayne Henry. 2012. “The Impact of Petition Signing on Voter Turnout." Political Behavior 34: 117-36.

Peterson, Paul E. 1981. City Limits. Chicago: University of Chicago Press.

Rimmerman, Craig A., Kenneth D. Wald and Clyde Wilcox, eds. 2000. The Politics of Gay Rights. Chicago: University of Chicago Press.

Rosenstone, Steven J. and John Mark Hansen. 1993. Mobilization, Participation, and Democracy in America. New York, NY, Macmillan Publishing Company.

Sapiro, Virginia, and Conover, Pamela Johnston. 1997. “The Variable Gender Bias of Electoral Politics: Gender and Context in the 1992 U.S. Election," British Journal of Political Science 27: 497-523.

Smith, Daniel A. 2012. "Direct Democracy_Regulating the 'Will of the People," in Matthew Streb, ed., Law and Election Politics: The Rules of the Game, 2nd edition. New York: Routledge.

Smith, Daniel A., and Caroline J. Tolbert. 2004. Educated by Initiative: The Effects of Direct Democracy on Citizens and Political Organizations in the American States. Ann Arbor: University of Michigan Press.

Stein, Robert M., Keith E. Hamm, Patricia K. Freeman. 1983. “An Analysis of Support for Tax Limitation Referenda." Public Choice 40: 187-194.

Wolfinger, Raymond E. and Stephen J. Rosenstone. 1980. Who Votes? New Haven, CT, Yale University Press. 